\title{
Space Transformation Due to Conflict: Changes from Agricultural to Industrial Space in Manyar District, Gresik Regency
}

\author{
Muhammad Mukhobbir Risalah
}

Department of Political Science, Universitas Airlangga, Surabaya, Indonesia e-mail : epehrisal@gmail.com

\begin{abstract}
Changes in the spatial area showed the dynamics of political economy. There is a problem regarding power relations in reproducing space, which will trigger a conflict between interests. These land changes, especially those related to changes in the form of agricultural land use to non-agricultural, have resulted in the loss of income sources for farmers. This paper focuses on the transformation of agricultural land into a nonagricultural one caused by conflict between several elements, including the local government, private businessmen, and the community, especially fishpond farmers who experience marginalization of agricultural land due to industrial development in Gresik Regency. The research is conducted using a qualitative approach with a descriptive type to support more in-depth research in analyzing urban spatial planning issues in the perspective of seeking spatial politics in Gresik district. The current reality is that the government tends to be more aligned with capital owners, which implies that spatial planning is manifested by profit-oriented development, high economic growth, and accumulation. The government mostly ignores ecological and social dimensions, which it considers nonlinear with economic investment.
\end{abstract}

Keywords-Transformation, Spatial Planning, Conflict, Agriculture, Industry, Political Economy.

\section{INTRODUCTION}

G RESIK Regency is currently one of the largest industrial cities in East Java, with hundreds of industries ranging from large-scale to home industries. In the last ten years, the number of industries in Gresik Regency has reached 6,451 businesses, and 1,423 of them are large/medium industries. In terms of economic turnover, the industrial sector in Gresik Regency is the largest sector seen from the distribution of gross regional domestic income (GRDP). The industrial sector contributed the most, with $48.20 \%$ of the total GRDP [1]. However, the development of industrialization has not only a positive impact on the economic side and but also a negative impact on the production of space. There have been many land transfers from agricultural lands to industrial lands.

Historically, the development of the first modern industry in Gresik Regency started in 1953 with the establishment of PT. Semen Gresik and continued in 1972 the establishment of PT. Petrokimia Gresik in Gresik district [2]. The presence of these large industries encourages the development of residential spaces such as trade centers and public facilities that approach these industrial spaces. The accumulation of these developments is the density of space between industry, settlements, and trade centers in Gresik district and the expansion of the Kebomas sub-district. The relatively high economic growth and the increasing level of urbanization have made these two regions a center of development.

The rate of industrial development in Gresik Regency is growing rapidly. The presence of these two large industries also impacted the development of other industries, including buffer industry and other different industries. Many urban space anomalies are dominated by the industrial sector, settlements, and other public facilities in a zone that is close to each other without a buffer zone and green open space (green belt).

Changes in spatial planning in urban areas, which are characterized as modern industrial cities, has affected the community and investors or developers to build factories, warehouses, ports, transport of goods, and others. Indeed, these developments are the forms of investment related to changes and demands of the global economy. Aldo Rossi has argued in his book The Architecture of the City (1966) that economic strength is a determinant of the transformation of a city. This is where the paradox of urban development often occurs: when the economic determination is so high that it marginalizes other dimensions such as ecology and social society [2].

The too dominance of development that is focused on the aspects of economic growth in urban development indicates that the government will relinquish urban spatial policies to market mechanisms and capitalist forces such as giving large industries the freedom to choose land. This phenomenon explains the thinking of Lafebreve [3] that urban spatial planning becomes a battleground for capitalism hegemony. Urban spatial planning concludes the existence of capitalism to produce space, so that space becomes a commodity arena that alienates interests outside the economy, such as ecology and social. The existence of a collaboration of interests between the government (government) and the private sector (market) that marginalizes ecological and social interests will trigger a conflict between the community, government, and capital.

A conflict will arise when different interests cannot be compromised. This, in turn, will create minority groups and majority groups. The existence of an intense degree of sense of belonging to space by certain groups raises concerns and tensions because of the competition for the character of space, which is mutually attractive. This conflict of interest occurs because there is no agreement between interest groups, especially in areas that have potential and are needed by each party. 
A city spatial planning policy should involve citizens in policy making so that sustainable development aspects are established. However, the reality is that it is often reversed. Noorena Hertz once argued that the current government prefers to ally with minority capital owners rather than the majority public interest [4]. It was at that time that political practices were more dominant in the interests of groups and individuals who had very strong access to capital. The implication is that urban spatial planning is directed at profitoriented development and high economic accumulation. They (the state) ignore the ecological and social dimensions which they consider non-linear with economic investment.

The ecological dimension that is affected by land relocation is an aquaculture/agricultural area located in Manyar District, this area is a milkfish pond fishery center. 4035 people live in the Manyar sub-district working as pond farmers with 5,833.11 ha of fishing land [5]. Many people who live in Manyar sub-district depend on agriculture and fisheries for their lives. Over time, there have been many changes in land use. The trend of changes that occur is due to changes in land use. Changes in land use in Manyar District indicate a change from agricultural land, vacant land, and green belt to industrial and residential areas.

The rapid industrial development in Manyar District will have an impact on the marginalization of fisheries land. The acceleration of industrial development at this time will be a threat to aquaculture farmers who own aquaculture lands. Industrial development in Gresik Regency tends to be fast and wild. The economic expansion of capitalism does promise instantaneous development as well as an impact on the rapid spread of the economy around it. However, behind this fastpaced and uncontrolled development expansion, it has actually led to directionless urban spatial planning and experiencing city density in a very short time.

These land changes, especially those related to agricultural land use to non-agrarian, have resulted in the loss of farmers' income sources. In this case, it will result in a decrease in the number of residents who are farmers. The closer they exist to the urban land, the more significant the proportion of farmers who change their profession to non- agriculture [6].

Agricultural lands that have been dominated by the surrounding non-agricultural lands will be detrimental to agricultural activities. Such as disruption of irrigation flow, the more agricultural pests are due to industrial areas adjacent to agricultural land, the more disturbances in the quality of irrigation water due to water pollution by industrial activities will cause their agricultural commitment to fade. In some cases, though, farmers can still overcome the problems their farm land.

According to Harvey [7], there is a complex process of modern urban spatial planning activities where the owners of capital will not stop producing profits on the space they have and their success in building space consumed by individuals. In fact, the capitalists are able to make buildings such as houses, apartments, hotels with a rental or purchase system [8]. This capitalist activity in producing endless space will marginalize agricultural and fishery land in the Manyar District area. What is happening now is that agricultural land in Manyar District has begun to be trapped by nonagricultural lands, negatively impacting the agricultural sector incomes. Many pond farmers have experienced crop failure due to industrial development along the main road in Manyar District.

This paper focuses on the transformation of agricultural land into non-agricultural due to conflicts between several elements, namely the local government, the private sector (business), and local communities, especially pond farmers who experience marginalization of agricultural land due to industrial development in Manyar District. Space is produced by the private sector by building power relations with the government. In the current reality, government tends to be more aligned with capitalists, which is that spatial planning is realized by profit-oriented development, growth, and high economic accumulation. The government mostly ignores ecological and social dimensions which it considers nonlinear with economic investment. Therefore, this paper wants to see how the spatial planning policies made by the Regent of Gresik Regency with a focus on the study of the Gresik regency spatial plan (the focus of discussion on the placement of industrial estates in Manyar sub-district). In addition, this study also examines the history of the beginning of industrial development in Gresik Regency.

\section{METHOD}

The researcher uses a qualitative approach with a descriptive type to support more in-depth research to analyze urban spatial problems in the perspective of seeking spatial politics in Gresik Regency. The descriptive qualitative method puts forward what is called meaning through neverended exploration processes, as the society as a social system that constantly changes produces continuous realities [9]. The unit of analysis in this research is to examine the spatial plan made by the Regent of Gresik Regency, where the regulation has an impact on the ecological and community dimensions that are not linear with political economy investment and also examines the history of industrial development in Gresik Regency.

Researchers studied the Gresik Regency Regional Regulation Number 8 of 2011 concerning the 2010-2030 Gresik Regency Spatial Plan. This study uses two kinds of qualitative data collection: a review of written documents and collecting issues about spatial transformation in Gresik Regency. Other data collected by researchers include data on changes in existing spaces, data on issues that cause conflicts of interest between actors in spatial planning and utilization, and the history of industrial development in Gresik district.

There are three lines of qualitative data analysis, namely data reduction, data presentation, and conclusion drawing. The data reduction process involves selecting various data that have been obtained through the previous stages so that they become relevant data for the research analysis unit. The presentation of data is through collecting issues that cause conflicts of interest between actors in spatial planning and spatial use and is then linked to conceptualization and theorizing frameworks. These issues are supported by documentation in the form of local regulations, tables, and data that have validity. 


\section{RESULT AND DISCUSSION}

\section{A. History of Industrial Development in Gresik Regency}

The initial progress of Gresik Regency development began around the port of Gresik City to the west side of the Gresik square. Gresik Harbor in the 14th century became the entrance to trade and the spread of Islam in Java. Subsequently, the development of the city took place rapidly, running following Governor Suryo's arterial road network towards Manyar and Jalan Pahwalan, and Jalan Veteran to the south. However, when the trading port was moved to Surabaya, the city of Gresik experienced a stagnant development and tended to decline. This lasted until 1950, which was called the pre-industrialization year. Due to the growth stagnation factor, until the beginning of independence, Gresik Regency was still a city of 'kawedanan' (commoner) under Surabaya, named Praja [2].

The second phase was the development of industrialization in the City of Gresik begins with the development of the PT. Semen Gresik in 1953 and PT. Petrokimia Gresik in 1972 which played a role in shaping the spatial structure of the city of Gresik. The existence of these two state-owned enterprises on a national scale impacts the rapid growth of the city of Gresik, especially around the two industrial areas. Finally, the city of Gresik, which initially only developed around Gresik Square and Gresik Harbor, also developed in these two large industrial areas.

The third phase was the emergence of developments using the concept of a new, independent city in the Kebomas area. The direction of urban growth in Gresik Regency tends to move to the west, following the arterial pathway towards the Duduksampeyan District and towards the north, namely the Manyar District. The industrial development in Gresik district has begun to develop along an arterial road to the north, to be more precise to Manyar District where industries such as the Plywood wood industry, PT. Maspion was built. Further to the west, there is an international port where the port development and become an integrated industrial area, namely JIIPE (Java Integrated Industrial and Port Estate). JIIPE is a third-generation industrial area. This categorization refers to the completeness of the supporting infrastructure available, especially the integration between industrial estates and ports. The JIIPE area has an industrial area business permit covering an area of 1,761 hectares. In this area, it can accommodate 183 industries.

\section{B. Industrialization And Fishing Areas In Gresik Area}

Industrialization is one of the development models undertaken by developing countries that are pursuing the optimization of economic growth. Industry is one of the longterm goals in fundamentally changing the structure of the economy from its initial focus on agricultural products. Therefore, its presence will give rise to what is called an industrial society, which is in contrast to an agrarian society. The development of the industrial sector cannot be separated from the development of other sectors, such as settlements around industrial areas. Industrialization always coincides with urbanization so that in its development, it will form the density of the city. The arrival of residents crowding the industrial centers will create further urban expansion. This phenomenon has been experienced by Gresik district for the last forty years.

Industrial estate in Gresik district, according to the Regional Regulation of Gresik Regency No. 8 of 2011 Article 70 on RTRW Gresik Regency 2010-2030, the use of industrial areas as referred to in Article 65 letter e with an area of approximately 12,448,026 ha, consists of large industrial areas, medium-sized industry, and home industry. The industrial area in Gresik district is planned for $9.81 \%$ of the land area or $11,728 \mathrm{ha}$, and is prioritized to be in the subdistricts of Ujungpangkah, Manyar, and Sidayu with an area ranging from 1,000-4,000 ha. Specifically for Gresik and Kebomas sub-districts, only $1.43 \%$ of the total industrial allocation was allocated, namely 23.95 ha in Gresik and 100.05 ha in Kebomas. Meanwhile, the utilization of aquaculture areas has an area of approximately 21,678,358 ha. It consists of a brackish water cultivation area and a freshwater cultivation area [10].

The aquaculture area in Manyar sub-district has experienced a relocation of fisheries land to industry due to the rapid development, which is considered one of the leading causes of declining income from the fisheries sector. Manyar sub-district is one of the fisheries centers for milkfish ponds in Gresik Regency. The relocation of fisheries land into industry are making fisheries areas marginalized, which causes the loss of livelihoods of local communities in the fisheries sector. This can be proven by the area of land fish maintenance in Manyar District as seen in Figure 1.

In 2011, the area of land fish maintenance in the brackish pond category in Manyar District had an area of 3,623.90 ha. Meanwhile, in 2019 the area of land fish maintenance has narrowed down to 3,124.06 ha. The narrowing of fisheries land in the brackish pond category is due to the Java Integrated Industrial and Port Estate (JIIPE) megaproject, in which the JIIPE development project is located in a brackish pond area in Manyar District.

The Java Integrated Industrial and Port Estate (JIIPE) megaproject is the largest project that integrates a deep seaport, industrial area, and residential area into one package, which is the cause of the land relocation. This international port area was built with 2,500 ha of land with the construction of a harbor of 85 ha with a length of 500meters. JIIPE is an industrial area that is integrated with deep seaport facilities and is equipped with related infrastructure and equipment. This area is divided into an industrial area of 1761 ha and a residential area of 766 ha. On Monday, $26^{\text {th }}$ October 2015, Indonesian President Joko Widodo released the JIIPE mega project to the US on a working visit to the United States. President Joko Widodo asked American entrepreneurs to invest their funds in the JIIPE Project. The impact of the JIIPE mega project has marginalized aquaculture land due to land relocation that has turned fishery land into industrial areas, housing, and other development projects. Many agricultural lands were sacrificed for the sake of JIIPE's development. Fishery land which is one of the main economies of the community in Manyar District must be sold 


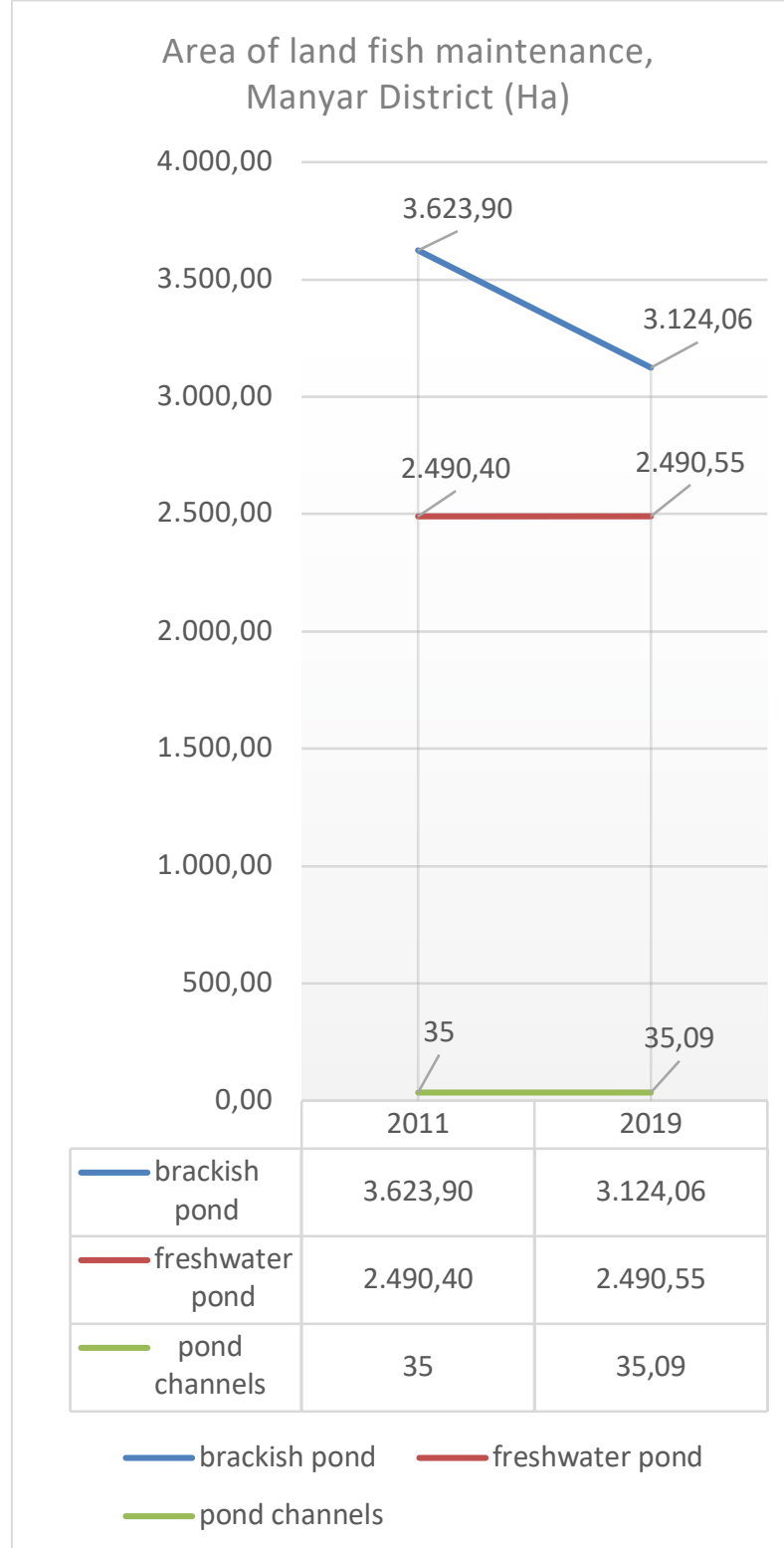

Figure 1. Area of land fish maintenance in 2011 and 2019.

to the government at a predetermined price, so that people inevitably have to sell their land due to land relocation. This will have fatal consequences for the local community for their agricultural land.

The transformation of land from a fishery area to a nonagricultural area has resulted in the shrinkage of agricultural land. These factory industries have also caused problems with road infrastructure damage, air pollution, environmental pollution due to factory waste. These damages have a negative impact on farmers in managing aquaculture because industrial and fishery areas are side by side.

\section{Analysis: Spatial Transformation Due To Conflict}

Currently, Gresik Regency has the status as one of the largest industrial cities in East Java, with hundreds of industries ranging from large scale to home industries. In the last ten years, the number of industries in Gresik Regency has reached 6,451 businesses, and 1,423 of them are large/medium industries. Of that number, a row of industrial estates has been established for a long time, starting the industrial complex of PT. Petrokimia which is connected to the Gresik industrial area, the complex along Jalan Darmo Sugondo, to those along Jalan Mayjen Sungkono.

Likewise, industrial development is located in non-city areas. As in Manyar, there is already a Maspion industrial complex (KIM) and several other centers. In the southern Gresik region, a number of areas have also become industrial complexes. For example, Weringinom, Driyorejo,Kedamean, and some Menganti. Moreover, most recently, a new industrial area megaproject was built in Manyar sub-district namely JIIPE (Java Integrated Industrial and Port Estate). The JIIPE area has an industrial area business permit covering an area of 1,761 hectares. In this area, it can accommodate 183 industries.

Industrial growth in Gresik district is predicted to increase because many investors have entered Gresik and there are still many land plots for industrial areas. According to the statement of Bapedda Gresik Task Husni Syarwanto in the pressreader (2015), "from the detailed management plan (RDTK) that has entered the review stage, the amount of land that is included in the industrial area plot is quite a lot. There are nine sub-districts where some of the lands have been plotted for industrial activities. Apart from the Manyar subdistrict, some areas have just entered the new plotting list, namely Ujungpangkah and Panceng. The two sub-districts are projected to become industrial buffer zones after the operation of JIIPE. Therefore, industrial growth in Gresik Regency will continue to increase until 2030 [11].

The ideology of urban development and spatial planning that refers to high economic growth has indeed become a trend of capital policies based solely on fulfilling economic existence. Capitalism is the main actor in carrying out the ideas of economic growth, market deregulation, political liberalization, free trade, privatization in the public sector to direct competition between the state and the market in serving the public. This can explain the idea of Harvey [7], that there is a complex process of modern urban spatial planning activities where capitalists will not stop in the activity of producing profits from their space. Therefore, industrial development in Gresik district will continue to increase and there will be many land changes and land conversion. This one will trigger a conflict of interest over the production of space.

The growth of the economic sector in an area triggers changes in space. The control of space in society continues to change along with the changing times, and it may be that the conditions can change radically, from being calm for decades to become a conflict. The existence of different spatial functions is one of the triggers for conflict. A conflict will arise when different interests cannot be compromised [6]. This, in turn, will create minority groups and majority groups in the change of space towards the formation of new spaces due to conflicts of interest. This conflict of interest occurs because there is no agreement between interest groups, especially in areas that have potential and are needed by each party. In Lafebre's framework of thought, the government as a regulator cannot ignore the use-value of a space, meaning that the government must become a facilitator and regulator in bridging the interests of society and capitalists. However, 
in reality, the current government is more dominant in the interests of the owners of capital.

According to Harvey [7], the government's attitude that is not neutral or in favor of capitalists is a necessity for the government to embrace capitalists, in addition to capitalists needing the government, including its support and political will to operate the second circuit of its capital and the first circuit, namely in the form of industrial development (manufacturing) and trading. Capitalists will continue to generate profits in the form of money and space. Space will be produced by building factories for industrial activities, the government's interest in capitalists is a form of investment as well as an engine for the growth of urban development.

The spatial problem in Gresik Regency is the relocation of agricultural and fishery lands to industrial lands. The Gresik district government has issued a regional regulation on the 2010-2030 regional spatial plan. The regulation has a profound impact on people who work as farmers. Land use changes that occurred in Manyar District resulted in a conflict of interest between the government, owners of capital, and local communities. The existence of development, in any case, must cause changes in it, such as changes in livelihoods. There are many people who have changed the function of land for the construction of the JIIPE port, especially farm workers whose economies depend on the fishery sector.

Not only do people inevitably have to sell their land, but there are also conflicts related to land acquisition for the construction of the JIIPE port. In the land acquisition for the construction of this international port, several actors were involved consisting of the Sambari Regent (government) and H. Syaiful who was the holder of the SPK (Work Order) for land acquisition for the construction of the JIIPE port, also represented by private parties consisting of PT BKM and PT BKMS, which is the project tender which assists in land acquisition.

The conflict in land acquisition began with the annexation of community land by issuing a fake Petok D contained a false statement containing the mutation of the land to the new land owner, even though the real land owner did not know each other. Land owners suffer losses because their land is sold unilaterally. Land owners cannot do anything because what they face is the upper class with the domination of power and the power of their resources. In this case, it shows the rent-seeking practices of the actors in land acquisition. Collaboration between the government and the private sector, who have great power and resources, tries everything they can to optimize interests regardless of the community's rights and interests.

From these problems, the construction of the international port belongs to the government and other elite rulers. The surrounding community cannot do anything about it and can only see the process of changing from what was previously an agricultural and fishery area to an international port and industrial land.

The reality of the existing spaces in Gresik district has undergone a socio-economic transformation and reorganization to serve the functions of management, utilization, service, and funding in a capitalist operating network. This causes the Gresik Regency government to continue to carry out production and reproduction of space to serve investors and capitalist forces, which are manifested through government policies so that many spaces have changed their function and allocation. The space that was originally a farm was turned into an industrial area.

\section{CONCLUSION}

Changes in the spatial show the dynamics of political economy. There is a problem regarding power relations in producing and reproducing space, which will trigger a conflict between interests. The Government of Gresik Regency uses its policy to give freedom to capitalists to produce and reproduce space freely.

Spatial development in Gresik Regency is dominated by the economic domain (economic centric) based on the accumulation of industrialized capital. This development is more concerned with capitalist interests with alibi to improve the people's economy. Thousands of large, small, and medium enterprises have continued to operate for decades. This will increase over the years and will continuously produce and reproduce space, resulting in agrarian degradation.

\section{REFERENCES}

[1] https://gresikkab.go.id/profil/pertumbuh_ekonomi (accesed on 9 December 2019)

[2] G, Geraldy, "Determination of industrial capitalism in urban spatial planning politics in gresik regency," Journal of Sociological Thought, Vol 4 No. 1, 2017

[3] H. Lefebvre, The Production of Space, Translated by Donald NicholsonSmith, Oxford: Blackwell, 1991

[4] N. Hertz, The Silent Takeover: Global Capitalism and the Death of Democracy, New York: HarperCollins Publishers, 2003

[5] Y. M. Yasa, The Influence of Industrial Development on the SocioEconomic Conditions of Farm Farmers in Manyar District, Gresik Regency, Surabaya, 2012

[6] H. S. Yunus, "WPU's Actual Spatial Problems", The Dynamics of PeriUrban Areas Determinants of the Future of Cities, Student Library. Section 6, section 6.3. pp. 355-358, Yogyakarta, 2008

[7] D. Harvey, The Urbanization of Capital: Studies in the History and Theory of Capitalist Urbanization, Oxford: Blackwell 1985

[8] S. Aminah, "Conflict and Contestation of Spatial Planning in Surabaya City,” LabSosio, Center for Sociology Studies FISIP-UI; 2015.

[9] H. Usman, P. S. Akbar. Social Research Methods. Jakarta. Earth Literacy: pp. 74-80, 1996

[10] Gresik Regency regional regulation number 8 of 2011 concerning the Gresik Regency spatial plan for the year 2010-2030

[11]https://www.pressreader.com/indonesia/jawapos/20150927/282660391227730 (accessed on 12 December 2019) 